\title{
Analysis of the influence of university network culture construction on
}

\section{campus cultural life}

\author{
Rui $\mathrm{Ma}^{1}$,Yue Wang ${ }^{2}$, Peng LV ${ }^{1 \star}$
}

${ }^{1}$ Beihua University ,Jilin, China

\begin{abstract}
${ }^{2}$ Beihua University, College of physical education, Longteng innovation and entrepreneurship education base
\end{abstract}

${ }^{*}$ Corresponding author: Peng Lv

Keywords: network culture, campus culture, influence analysis

Abstract: the construction of campus culture has become an active pursuit of the management and development of many schools. "The power of culture" is becoming a great impetus to the progress of education. Campus network culture, as a new carrier of school culture, can have a significant impact on school culture construction. Students and teachers are the participants and constructors of campus network culture, and the cultivation of students and teachers is the key to the construction of campus network culture. The use of campus network, and strive to cultivate humanistic environment, organize the content of healthy, elegant, rich and colorful campus culture activities, let the campus gradually formed a strong learning atmosphere, campus network culture and a healthy and civilized campus environment, so as to promote the increase of the whole campus civilization.

\section{I、 The current situation of College Students' network life}

The university campus has been in the front of the whole society, the network era is no exception. At present, college students dormitory universal networking, most students have their own computers, even if students do not have personal computers, colleges and universities also have larger, lower charge of the computer room for students to access the internet. Under such network conditions, it is very common for college students to surf the internet. The students need to apply the network, such as writing papers, checking materials, attending classes, handing in homework, contacting with teachers and communicating with their classmates, etc. the network has become an indispensable part of College Students' learning and life. The purpose and motivation of College Students' surfing the internet. It mainly includes the following aspects:

(1) satisfy the desire for knowledge. The Internet is the world's largest library and huge information base, all aspects of social life, politics, economy, culture, life, science and education, arts and other information are concentrated on the Internet, the rich information resources and diverse information like state college students expand avenues by knowledge and information.

(2) self actualization. In the virtual cyberspace, many real social constraints have disappeared. Everyone is the owner of the Internet, the network community is equal, everyone has the right to speak, you can express their opinions and suggestions for an event or problem. The online virtual identity, and the reality of college students can play different roles in the network, enjoy the network characteristics of equality, freedom, success, to stimulate the feeling of identity and role of network to meet their needs of self realization.

(3) psychological decompression. College students will encounter such setbacks and difficulties 
in their study and life. Nature also creates pressure on learning, feelings, relationships, and so on. The psychological drive system of human behavior consists of two psychological tendencies: one is seeking satisfaction and enterprising psychological tendency; the other is psychological tendency to avoid injury and defense. Because the network can anonymously vent their repressed emotions, the network has become a place for many college students to avoid loneliness and relieve psychological pressure. Internet has become an effective way to release psychological pressure and relax the mind and body.

(4) showing individuality. College students according to their own preferences, feelings. It can make full use of network hyperlink, network interaction and dynamic update features. Select and link to the Internet in that information, knowledge and resources value; can also be personal learning inspiration process, life stories, thoughts, through timely record and release, play unlimited personal expression; more can meet friends, friends and exchange. Communicate in depth. But we should see that the students in the process of using the network, there are some we are not willing to see the phenomenon: some people online is mainly to pass the boring time, they indulge in the network world, to avoid the reality, affect the normal learning, seriously affect the interpersonal relationship in reality, lead students in reality social communication is weakening, interpersonal indifference, alienation and even social reality.

\section{II、The necessity of University Network Culture Construction Research}

The new media rapid development of College Network Culture Construction under the form of in-depth research, its significance is mainly reflected in: first, you can try to avoid the harm of unhealthy factors in the network of college students, guide students to correctly use the network, network culture guide the healthy development of. Secondly, it is beneficial to improve the work style, improve work efficiency, facilitate the school to grasp the students' ideological trends better, facilitate the sharing of learning resources and promote the reform of teaching. Again, the healthy development of the network culture plays a very important role to enrich the campus culture, with the network culture construction, campus culture construction will be further diversified, but in the modern university free and inclusive, this diversity is necessary.

Only by recognizing the necessity, tasks and Strategies of the construction of network culture in Colleges and universities, can we promote the prosperity and development of network culture construction. In the perspective of new media, in-depth study of this problem, undoubtedly has a certain significance.

\section{III、The influence of network culture on campus life}

Network is a double-edged sword, which has positive and negative influence on the growth and development of College students.

(1) the positive influence of network culture

The openness of Internet culture to broaden the horizon of college students, college students can understand the construction and development of the school through the network, and put forward reasonable suggestions; through the network can click online teaching video, classroom learning outside; can communicate online with the teacher; through the electronic library access to relevant professional literature and information, more quickly understanding of the latest academic developments, to stimulate interest in learning.

The subjectivity of network culture is conducive to the formation and development of College Students' creativity, and to cultivate their own subjective initiative. The equality and virtuality of network culture is beneficial to the development of College Students' personality and the improvement of self consciousness. Equality of network communication, creating opportunities for college students' personality, anyone can enjoy the show yourself on the Internet, many students 
from the network communication to deepen the knowledge of self, have a more mature self evaluation. Network society from the university students themselves, to meet the realization of self-worth of College students.

(2) the negative influence of network culture

First, the network weakens the moral consciousness of College students. Openness and freedom of the network is conducive to the development of College Students' personality, but also brought anarchy let things drift. Anarchism and liberalism directly lead to the confusion of College Students' moral consciousness, thinking that they can do whatever they like on the Internet without any responsibility. Some students were released pent up personality, carried away in the virtual world of cyberspace, but in the network behind the prosperity, there is the invasion of privacy, harmful information, Lieyan, malicious personal attacks and modern civilization misfits.

Secondly, the network attacks the traditional values of College students. The traditional school education value orientation is positive, but the emergence of the network makes college students understand the channels of information more widely. As a result, educators' authority in disseminating information has been broken. In addition, the collision and conflict between the values of the East and the West in the minds of the students is more direct, shaking the existing pursuit of faith and norms of conduct, resulting in confusion and confusion of value standards.

Thirdly, the network culture weakens the traditional form of interpersonal communication to some extent, which leads to the virtualization of interpersonal communication and the alienation of the real relationship. The interactive model of change, but also easy to make students have some sense of exclusion of interpersonal communication in real life, resulting in solitary, indifference, lack of emotion, and thus lead to various psychological problems, not harmonious factors.

IV 、Countermeasures for construction and management of campus network culture in Colleges and Universities

(1) to improve the efficiency of campus network culture construction and management of strengthening the management of campus network in Colleges and universities, to improve the efficiency of campus network culture construction and management, is the objective need to occupy the position of the ideological and political education. First of all, gradually improve the network software and hardware facilities, to solve the network speed of the campus network construction is too slow, the school computer room computer configuration is low and other issues, the school can allocate special fund, take corresponding measures to further improve the school computer room and library network facilities for hardware and software upgrades. Secondly, optimizing the construction of campus network culture and management organization system, strengthening the campus network management work is the realistic requirement of adhering to the education oriented and moral education first. Reasonable campus network management system can make effective and smooth communication between teachers and students. Therefore, we should adhere to the principle of "who is in charge, who is responsible, who is responsible, who is responsible, who is responsible", we can not ignore the importance of the technical level to the construction of campus network culture.

(2) the construction of campus network culture environment harmonious and heritage platform to organize the implementation of the "green campus network plan, carry out a civilized and civilized site creation activities, expand the mainstream public opinion, to encourage students to consciously resist the harmful information, network abuse and vulgarity. To create a wonderful lesson, online, online forum famous lecture hall and a number of campus network culture brand, cultivating humanistic quality and scientific spirit, the school tradition, strengthen the campus network culture affinity and cohesion. Actively expand the network of schools, television, network 
radio, cyber source download network media form, broaden the campus network construction, employment services, group counseling, emotional hotline and other activities, to further play the function of campus network service for college students.

(3) create academic exchanges and scientific and technological innovation platform

Constantly enrich campus spiritual and cultural life is to further enrich the content of the campus network culture as the premise. The distinctive feature of the university is that it has a strong academic atmosphere, is an important source of new knowledge, new ideas and new technology, and is also the cradle of training advanced professionals. Colleges and universities must set up campus network interactive platform for College Students

To provide adequate information and resources, to create a different academic characteristics of campus network culture, and play the main role of teachers and students, stimulate the students' thinking ability and creativity through the network, provide a good environment for technological innovation. Therefore, the campus network must make itself become the guidance of science and technology information resources, and become the platform of science and technology communication and innovation. In a word, the society should give the construction and management of campus network culture more attention and research, through the campus network culture practice and Exploration on the construction of a harmonious, people-oriented, with China characteristics.

\section{Acknowledgement}

This paper is the subject of Beihua University: the research achievements of the research on the management mechanism of network culture construction in Universities under the new situation. (NO:201751)

\section{[References]}

[1] Lan Wei Qing, Xie Jing, Cao Jianmin, et al. Investigation and Research on the network use of college students [J]. Higher agricultural education, 2009 (7)

[2] Li Chengen, Zhang Yanjun, Cui Qiang, Wei Yuan. Influence factors and Countermeasures of network culture construction in Colleges and universities [J]. ideological education research, 2016, (05): 101-104

[3] Du Yue. Research on network culture construction of universities in China under the background of globalization [D]. Northeast Agricultural University, 2015

[4] Teng Xiaochun, Guo Zhihong. Importance of strengthening the construction of university network culture in the new era [J]. Journal of Chifeng University (NATURAL SCIENCE EDITION), 2013,29 (18): 249-251.

[5] Liu Yong, Zhao Liying, Zhang forest. The culture of campus network construction present situation and Countermeasure of [J]. Journal of Northeast Agricultural University (SOCIAL SCIENCE EDITION), 2014,12 (02): 107-109+114. 